\title{
An Impact of population on Minor Irrigation Projects Warud Tahsil, Distrist Amravati, Maharashtra
}

\author{
Dr. Shalini M. Guldeokar ${ }^{1}$, Dr. Aruna P. Patil ${ }^{2}$, Prof. Mangala M. Kanate ${ }^{3}$ \\ ${ }^{1}$ S. P. College, Department of Geography, Tilak Road, Pune, Maharashtra, India \\ 2Professor, Rajabhau Deshmukh Kala Mahavidyalaya, Nandgaon Khandeshwar, Amravati, Maharashtra, India \\ ${ }^{3}$ Late Panchafulabai Pawade Art and Commerce Mahavidyal ,Warud, Amravati, Maharashtra, India
}

\begin{abstract}
Irrigation is a major input for the development of agriculture in any country, the greatest development in the history of mankind was the discovery of agriculture and then irrigation. Irrigation has been practiced from very ancient times in our country; irrigation assumes paramount importance lest the vagaries of nature and uncertain rainfall lead to ruining of crops resulting in famine conditions. Irrigation serves a dual purpose in agriculture, it provides protection to crops against destructions and damage by failure of rainfall and irrigation helps to increase yield of crops even in normal condition. Hence irrigation is important, without irrigation agricultural production could not increase, but for that water is necessary for practice of agriculture. In India agriculture is carried out with the help of irrigation. Irrigation means supply of artificial means of water, it is one of most crucial inputs in the process of agriculture development, so significant efforts have been made the develop the irrigation potential through the projects. Some time minor irrigation projects play vital role in transforming the agriculture into productive agriculture as well as changing the overall social-economic structure of the area similarly agriculture gets stability also. Hence in this research paper an attempt has been made to how impact on population of minor irrigation project in Warud Tahsils.
\end{abstract}

Keywords : Agriculture, Development, Discovery, Famine, Irrigation, Productive, Transforming

\section{INTRODUCTION}

The term agriculture includes several activities that are closely related to growing crops, agriculture is influenced by physical factors because soils are very important for growing crops. Early Indus valley civilization started in India was gifted by nature several rivers, fertile soils ample sunshine and favorable climatic conditions for agricultural practicing. India has monsoon climate and has seasonal rainfall and uneven rainfall distribution its affects on agriculture so we require irrigation facilities for good agricultural production. Because 70 percent population is depends on agriculture and more than
60 percent national income comes from agriculture, to fulfill the food grains demand of population we have to focus on agriculture for that water or irrigation is necessary. Irrigation is major input for development of agriculture, irrigation means supply of artificial means of water. The practice of irrigation in India is as important source of human civilization. Gradually irrigation came to practiced not only on river banks but further inland by means of open well, tanks and canals on a larger scale.

Irrigation is one of the most essential inputs in the process of agricultural development. So significance efforts have been made to develop the irrigation 
potential through the projects. Sometime minor projects plays very important role in transforming the agriculture into productive agriculture as well as changing the overall socio-economic structure of the area. Due to Orange cultivation Warud tahsil is known as California of Vidharbha.

\section{STUDY AREA}

Warud tahsil is located in Amravati district of Maharashtra; it is extremely located in east part of district. The study region is extends between $21^{\circ} 28^{\prime} \mathrm{N}$. to $21^{\circ} 29^{\prime} \mathrm{N}$ latitudes and $78^{\circ} 16^{\prime} \mathrm{E}$ to $78^{\circ} 17^{\prime} \mathrm{E}$ longitudes, approximately 743 sq.km. area has covered, total number of villages came under this tahsil is 140 , out of this 119 villages are habited and 21 villages are inhabited. According to census 2011 total population of tahsil's is 224948 and density of population is 303 per sq. $\mathrm{km}$. and sex ratio is 945 . (Map 1 and Map 2)
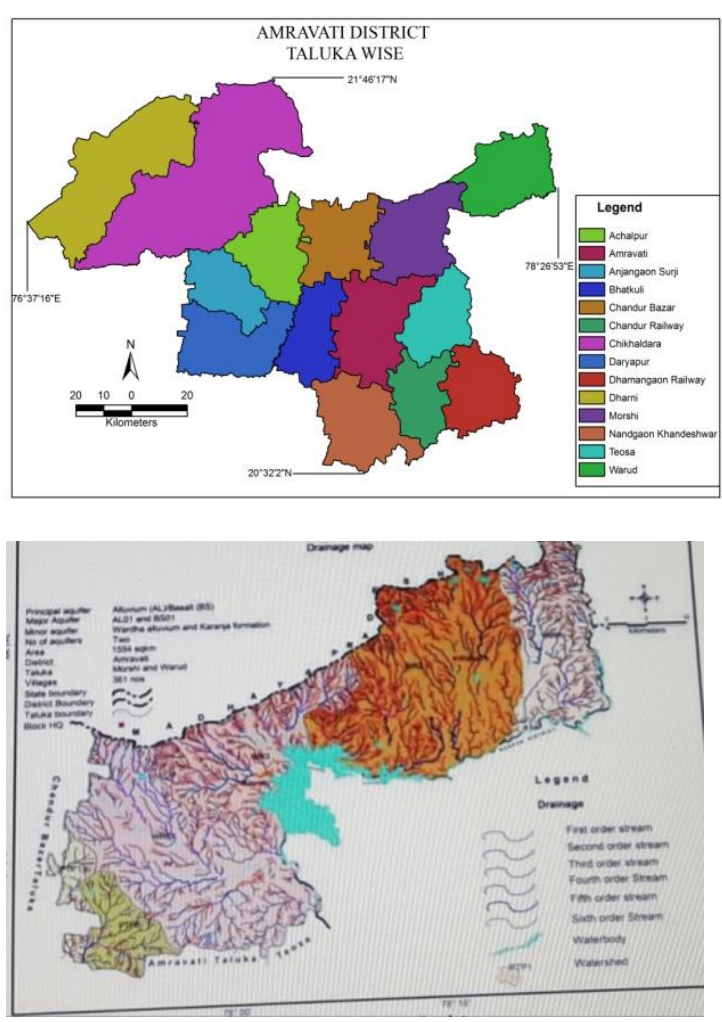

Warud has an agricultural-based economy. Shendurjana Ghat, Isambri-Bahada and Tembhurkheda are the main exporters of oranges in Warud taluka. Thus, water is the main constraint for this business. Problems related to water affects economic development and hence it is essential to avoid these constraints. To remove these constraints, different mini projects are developed in warud taluka such as pusli dam, Wai dam, Shekhdari dam, Nagthana dam, Jamgaon dam, Jamalpur dam, Satnur dam, pandhari dam, Belsawangi dam.

\section{Objectives of the study}

1. To Study effect of minor projects on population of warud tahasil

2. To study the importance of Minor Research projects

\section{Database and Methodology}

Present study is based on primary and secondary data. Primary data have been collected through questionnaire and field work; for sample survey ten percent farmers are interviewed here an attempt is made to measure the water consumption by per farmers for irrigation. Secondary data have been collected from irrigation department and socioeconomic abstract and census hand book etc.

To represent this data suitable statistical methods and cartographic techniques has used.

\section{Analysis of Data}

For the agriculture development not only the study of geographic components is essential but also the study of irrigation projects is important. For the study of irrigative projects primary, secondary and tertiary components are to be considered. From the numerical computation of population annual, social budget the 
magazines related to the agricultural progress and study can be made.

The geographical area of this region is 54496 hectors out of which 53800 hectors of land is used for irrigation. Various components such as tube well, wells, dams are used for irrigation. As the water levels in this area has decreased wells and tube wells are not so useful hence minor irrigation projects is implemented in this area and is proving beneficial for agriculture. Important dams in Warud tasils are pusli dam, Wai dam, Shekhdari dam, Nagthana dam, Jamgaon dam, Jamalpur dam, Satnur dam, pandhari dam, Belsawangi dam but Shekhdari dam, Nagthana dam and Wai dams are most important. This water is used for different purpose such as drinking, agriculture and industry also. Considering lack of water availability and to save water sprinklers and drop irrigation methods are using. It has been observed that in Warud tahsil total irrigation area is 132.45 sq.km amongst them 47.80 sq.km area under drip and sprinkler irrigation this irrigation methods are used to take different crops.

Table 1. Water Storage Capacity of Dams

\begin{tabular}{|c|c|}
\hline Dams Name & $\begin{array}{c}\text { Storage Capacity } \\
\text { MCM }\end{array}$ \\
\hline Shekhdari dam & 5.22 \\
\hline Nagthana dam & 2.55 \\
\hline Pandhari Dam & 0.94 \\
\hline Satnoor Dam & 1.54 \\
\hline Wai Dam & 2.78 \\
\hline Waghad zunj & 1.75 \\
\hline
\end{tabular}

Source : Irrigation Department, Govt. of Maharashtra, June 2005

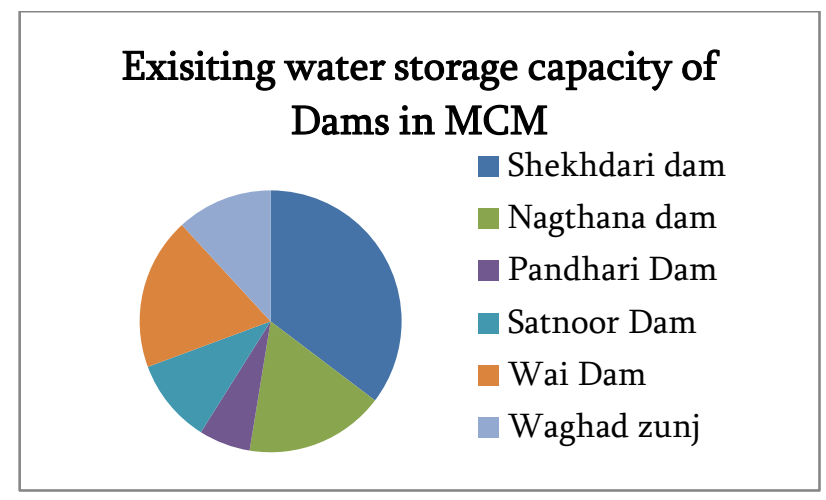

Fig 1

It has been observed that although due to limited availability of irrigation resources farmers have puts their efforts for the cultivation; it has also been observed that for cultivation farmers have made the use of all available irrigative resources change has occurred in the areas wherein water has been supplied from these dams. Because of implementation of minor irrigation projects with the supply of water from dams it helps to increased production of kharip and rabbi. 60 percent farmers have got employment due to implements of irrigation projects, there has been tremendous change in cultivation of crops, cotton is mainly cultivated in this area due to irrigation along with cotton, chilly, orange, wheat, turmeric, grams, grapes, fruits and dairy business also has started.

Table 2. Area under Different Crops

\begin{tabular}{|l|l|}
\hline Name of crops & Area in sq.km. \\
\hline Oil Seeds & 33.91 \\
\hline Pulses & 38.22 \\
\hline Oranges & 98.57 \\
\hline Cereals & 194.30 \\
\hline Cotton & 68.59 \\
\hline
\end{tabular}

Source: Irrigation Department, Govt. of Maharashtra, June 2005 


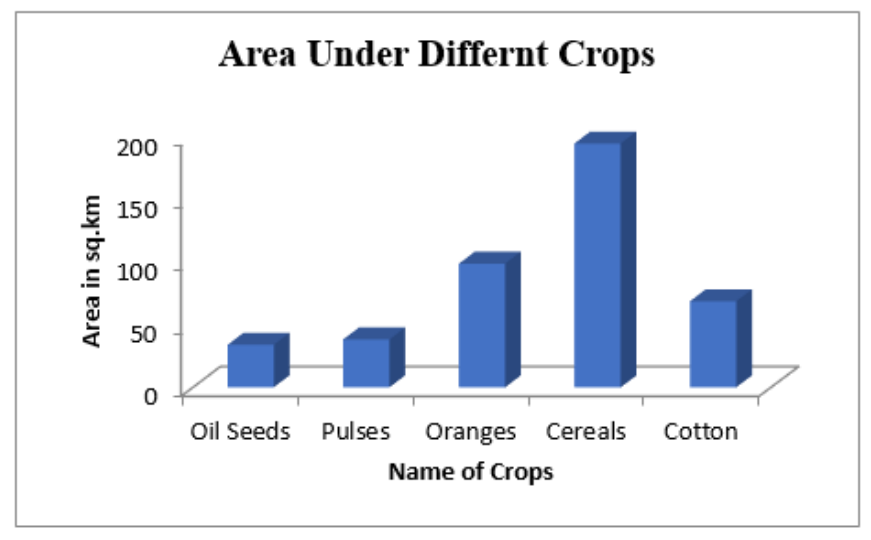

Fig 2

The ground water is the most dependable source of water supply at the time of crop requirement, in Warud it can observed 119.37 sq.km area based on ground water irrigation and surface irrigated area is only 13.08 has observed. Although, the facilities for drip irrigation are exists but the farmers are still prefer to irrigate the orange orchards by traditional flood irrigation method, which causes undue feeding of ground water because of irregular electricity supply, high maintenance cost of drip and sprinkler irrigation system.

The implementation of minor irrigation projects has proved that it is beneficial to socio and economical point of view; because population is one of the main treasure of the country with invent new ideas if efforts helps to improving the economic status of country. While considering population of any region rural and urban both populations are important in Warud tahsil rural population is more hence more people are engaged in agriculture so they are depends on dam's irrigation because it is drought region to save agriculture government has implemented eleven small, minor and major projects in this area.

\section{v. CONCLUSION}

This minor projects help to increase productivity in warud tahasil of oranges and other Crops

2. Sixty percent farmers state that these minor projects are very useful because they are producing more production and gaining more profits and becoming economically stable.

3. Its motivate farmers to adapt new methods.

4. Farmers are using drip and sprinklers irrigation methods to save water.

\section{REFERENCES}

[1]. Government of India: 2017 Report on Aquifer Maps and Ground Water Management Plans: Warud And Morshi Talukas, Amravati District, Maharashtra

[2]. Dr. Madar Y. M. "Water Scarcity- A Case Study Of Hubli-Dharwad Twin Cities" The deccan Geographer, Vol. 40, Jan-June 2002. Pp 31-42

[3]. Mushir Seemin and Mohd. Firoz Khan "Water logging hazard in Saharanpur city- A Geographical Analysis" The Deccan Geographer, Vol. 45, No.1 June 2007, pp 1-8.

[4]. Dr. Nageshwar Pradas and Ms. Malavika Sinha "Potential,Utilisation and Management of ground water in the Northwest Bankura District, West Bengal" Trans. Inst. Indian Geographers, Vol. 28, No.1, Winter 2006, pp 57-67.

[5]. Verma K.N.: Irrigation Department (Minor irrigation division Amravati).

Cite this Article : Dr. Shalini M. Guldeokar, Dr. Aruna P. Patil, Prof. Mangala M. Kanate, "An Impact of population on Minor Irrigation Projects Warud Tahsil, Distrist Amravati, Maharashtra", International Journal of Scientific Research in Science and Technology (IJSRST), Online ISSN : 2395-602X, Print ISSN : 2395-6011, Volume 7 Issue 2, pp. 502-505, March-April 2020. Available at doi : https://doi.org/10.32628/IJSRST207289 Journal URL : http://ijsrst.com/IJSRST207289 